\title{
Implementation of Village Fund Policies (Study on the Realization of Village North Hamak Village, Telaga Langsat District)
}

Fathul Mushalli ${ }^{*}$, Andi Tenri Sompa, Jamaluddin

Masters in Development Administration, Postgraduate Program, Lambung Mangkurat University, Banjarmasin, Indonesia

DOI: $10.36348 /$ sijlcj.2021.v04i02.013

| Received: 08.02.2021 | Accepted: 20.02.2021 | Published: 26.02.2021

*Corresponding author: Fathul Mushalli

\section{Abstract}

This study aims to analyze and provide an overview of the implementation of village fund management in Hamak Utara Village, Telaga Langsat District, and Hulu Sungai Selatan Regency and to identify factors that influence the implementation of village fund policies in North Hamak Village. The research method used in this research is the descriptive qualitative method. The types of data used in this study are primary data and secondary data. The informants in this study were the head of the sub-district and the technical head of Telaga Langsat sub-district, village assistants and village local assistants, village heads and village officials, Hamak Utara village consultative bodies, RT / RW in North Hamak village, and Hamak Utara village community. Data collection techniques used in this study were interviews, observations, and documents, and archives. The data analysis techniques used in this study were data reduction, data classification, data processing, and data inference. The results showed that the implementation of village fund management in North Hamak Village was running according to the provisions, but there were several obstacles in terms of budget implementation and absorption. Communication, attitudes, resources, and bureaucratic structures influence the implementation of village fund management in Hamak Utara Village, Telaga Langsat District.

Keywords: Implementation, policies, and village funds.

Copyright ( $) 2021$ The Author(s): This is an open-access article distributed under the terms of the Creative Commons Attribution 4.0 International License (CC BY-NC 4.0) which permits unrestricted use, distribution, and reproduction in any medium for non-commercial use provided the original author and source are credited.

\section{INTRODUCTION}

Village development aims to improve the welfare of the Village community and the quality of human life as well as poverty alleviation through the provision of the fulfillment of basic needs, development of facilities and infrastructure, development of local economic potential, and sustainable use of natural resources and the environment. The development of 74,754 villages and the smallest administrative area of the Unitary State of the Republic of Indonesia needs to be a concern because to achieve prosperity and equitable development for people throughout the territory of Indonesia should start from the smallest scope and most represent the conditions in the Indonesian territory to the outer borders of the Indonesian territory. So based on the Law of the Republic of Indonesia Number 6 of 2014 concerning Villages, the Indonesian government disbursed funds for villages called Village Funds which were disbursed gradually in 2015. Village Funds are funds sourced from the State Revenue and Expenditure Budget intended for Villages which are transferred through District/city Regional Revenue and Expenditure Budget and are used to finance governance, implementation of development, community development, and community empowerment. Law Number 6 of 2014 has mandated the village government to be more independent in managing the government and its various natural resources, including financial management and village property. The big role received by the village is of course accompanied by a big responsibility. According to Roza \& Arliman [1], the village government is required to apply the principle of accountability in its governance where the end of all activities of implementing village governance must be accountable to the village community following the provisions.

The Hulu Sungai Selatan District Government to implement policies on village development has distributed Village Funds to all villages in all Districts in Hulu Sungai Selatan Regency. If you look at the amount of budget given to villages through the Village Fund, which is up to an average of more than IDR $500,000,000 /$ village, then the question arises whether the village and its existing elements can carry out proper budget management. This is considering that previously villages only received limited financial 
Fathul Mushalli et al., Sch Int J Law Crime Justice, Feb, 2021; 4(2): 117-120

assistance and management was still very centralized by units of government agencies. So that doubts about the capacity of the village internally to manage the sizeable allocation of funds are still questionable. Besides, many villages still have certain limitations, especially in government organizations, so that this will also affect the management of the Village Fund. Wasistiono \& Tahir [2] stated that the elements of weakness possessed by village governments in general are (1) the low quality of village apparatus resources, (2) the incomplete regulatory policies regarding village government organizations, (3) low planning capacity at the level villages, as well as (4) very limited facilities and infrastructure to support government administration operations.

As an example, the problems in managing the Village Fund budget are experienced by the Hamak Utara Village Government, Telaga Langsat District, Hulu Sungai Selatan Regency. The Village Fund that has been distributed to Hamak Utara Village is Rp. $571,125,186$ only Rp. 221 . 668,000 or only $38.81 \%$. This makes researchers interested in exploring further because the village funds are not maximally realized and what obstacles are faced by Hamak Village in implementing the Hamak Utara Village Fund policy. So the researchers raised the research title "implementation of village fund policies (studies on the realization of village funds in Hamak Utara, Telaga Langsat subdistrict".

\section{RESEARCH METHOD}

The method used in this research is the qualitative method. Qualitative research is research that is intended to understand the phenomena experienced by research subjects. This research was conducted in North Hamak Village, Telaga Langsat District. The types of data used in this study are primary data and secondary data. Primary data were obtained from interviews with key informants regarding their knowledge of problems regarding the implementation of village fund management in Hamak Utara Village, Telaga Langsat District. Meanwhile, secondary data is processed data derived from tracing and reviewing documents and reports relating to the implementation process of village fund management in Hamak Utara Village, Telaga Langsat District. The informants in the study were the head of the sub-district and the technical head of Telaga Langsat sub-district, village assistants and village local assistants, village heads and village officials, the Hamak Utara village consultative body, RT/RW in North Hamak village, and the North Hamak village community. Data collection techniques used in this study was interviews, observations, and documents, and archives. Interviews were conducted to obtain information that was considered importantly related to the problems being studied both in terms of activities (activities) and people (actors). Then observations are made to see social facts and facts so that they can be matched between the results of interviews or information from informants with facts in the field, both in terms of activities and actors. Furthermore, a literature review was carried out where the researcher collected data from previous research in the form of books, journals, and theses. The data analysis techniques used in this study were data reduction, data classification, data processing, and data inference.

\section{RESULTS AND DISCUSSION \\ 1. Implementation of village fund management policies}

Planning in village fund management activities is the beginning of activities that provide information to coordinate work accurately and effectively [3]. In planning the use of Village Funds, it begins with the preparation or preparation of the RPJMDes (Village Medium Term Development Plan). The results showed that the village of North Hamak had prepared/had a village medium-term development plan which was then carried out by joint deliberations between the village government and community leaders. The technicalities invite the public to be able to play an active role in Village Musrenbang activities, namely by inviting written as well as oral. Based on the results of the document study, Hamak Utara Village has implemented representation of all elements of society and the results of the Village Deliberative Meeting form the basis for the preparation of the Village Government Work Plan (RKPDes). Based on the results of interviews conducted by researchers, it can be described that the planning process for the use of the Village Fund Budget carried out in Hulu Sungai Selatan Regency is as shown in Figure 1 as follows:

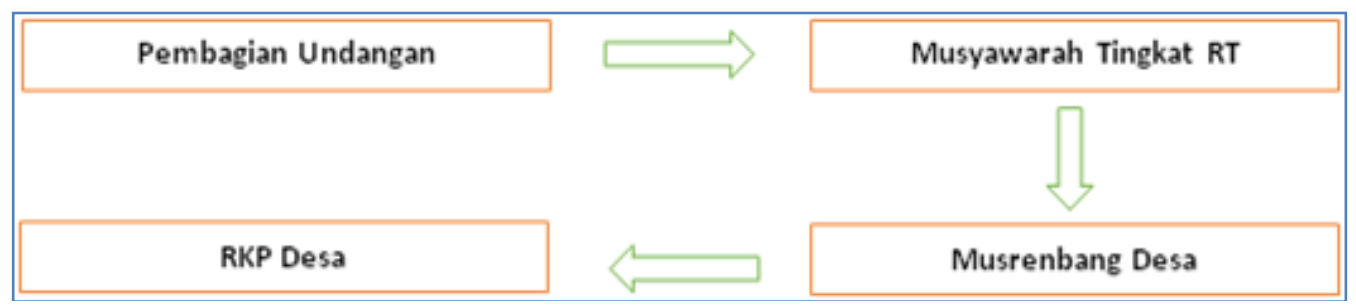

Fig-1: Flow of Planning for the Use of the Village Fund Budget 
Fathul Mushalli et al., Sch Int J Law Crime Justice, Feb, 2021; 4(2): 117-120

Furthermore, the results of the analysis of the planning for the use of the village fund budget in North Hamak village can be seen in Table 1 as follows:

Table-1: Analysis of Village Fund Budget Use Planning in North Hamak Village

\begin{tabular}{|l|l|l|l|}
\hline NO & STAGE & ACTORS/ROLES & ANALYSIS \\
\hline 3. & Meeting Per RT & $\begin{array}{l}\text { Head of RT, community, } \\
\text { and community leaders }\end{array}$ & $\begin{array}{l}\text { The village government involves all components in the } \\
\text { village, both social institutions and the general public. }\end{array}$ \\
\hline Distribution & Village Apparatus & $\begin{array}{l}\text { Village officials distributed invitations to all elements } \\
\text { of society, community leaders, NGOs, BPD, to attend } \\
\text { the Village Musrenbang process. }\end{array}$ \\
\hline 4. & $\begin{array}{l}\text { Village } \\
\text { Development } \\
\text { Planning Meeting }\end{array}$ & $\begin{array}{l}\text { Camat, Village Heads, } \\
\text { BPD, NGOs, Community } \\
\text { Leaders, and Communities. }\end{array}$ & $\begin{array}{l}\text { The Village Government gets work program proposals } \\
\text { from all elements present in the musrenbang process. }\end{array}$ \\
\hline 4 & $\begin{array}{l}\text { Preparation of } \\
\text { RKPDes }\end{array}$ & $\begin{array}{l}\text { RKPDesa Preparation } \\
\text { Team }\end{array}$ & $\begin{array}{l}\text { Preparation of RKPDes based on the results of the } \\
\text { Village Musrenbang. }\end{array}$ \\
\hline
\end{tabular}

Source: Analysis of document studies and interview studies, 2020

Based on the description above, it can be concluded that the planning for the use of the Hamak Utara village budget has already referred to the RPJMDes of each village. The RPJMDes are followed up at the RT level Musrenbang activities and finalized at the village musrenbang level and then determined through the RKPDes (Village Government Work Plan).

After planning, the next step in managing village funds is implementation. Implementation is the most important management function and encourages group members to strive to achieve targets according to managerial planning and organizational efforts [4]. Hamak Utara Village has been able to properly prepare RKPDesa documents, but in reality, it has not gone as expected. This is evident from the village funds that have been distributed to Hamak Utara Village in the amount of Rp. $571,125,186$ only Rp. $221,668,000$ or only $38.81 \%$. The realization of the village fund budget is more for routine activities, while physical activities or development are not realized as they should. Based on the results of interviews with several informants, it was stated that the inadequate implementation of activities in Hamak village was due to non-technical factors. The Village Government seems to be deliberately improper in realizing the planning for the use of the village budget.

The next step in village financial management is financial administration, namely recording activities carried out by the village treasurer. The village treasurer is obliged to record systematically and chronologically the financial transactions that occur either in the form of income or expenditure. The accountability report is submitted monthly to the village head no later than the 10th of the following month. The results showed that the financial administration documents in North Hamak Village had been completely fulfilled as illustrated in Table 2 as follows:

Table-2: Availability of Administration Documents in North Hamak Village

\begin{tabular}{|l|l|l|l|}
\hline \multirow{2}{*}{ Village } & \multicolumn{3}{|l|}{ ADMINISTRATIVE DOCUMENTS } \\
\cline { 2 - 4 } & General cash book & Tax auxiliary cash book & Bank account book \\
\hline Hamak Utara & Exist & Exist & Exist \\
\hline
\end{tabular}

Source: Document study, 2020

The flow of financial administration carried out in Hamak Village is as illustrated in Table 3 as follows:

Table-3: Financial Administration of Hamak Utara Village Funds

\begin{tabular}{|l|l|l|l|}
\hline No. & STAGE & ACTORS/ROLES & ANALYSIS \\
\hline 1 & Administration of Admissions & Village Treasurer & Recording of financial receipts has been carried out properly \\
\hline 2 & Administration of Expenditures & Village Treasurer & Recording of financial expenditures has been carried out properly \\
\hline 3 & Accountability Reporting & $\begin{array}{l}\text { Village Head and } \\
\text { Village Treasurer }\end{array}$ & $\begin{array}{l}\text { Every month the Village reports the financial condition of the } \\
\text { Village to the Village head }\end{array}$ \\
\hline
\end{tabular}

Source: Analysis of Interview, 2020

Based on the data in Table 3, shows that the administration process carried out by the treasurer runs following existing procedures, both administration of revenue to accountability reporting. Hamak Utara Village uses the village financial system application as a medium for recording village finances. Siskeudes (Village Financial System) is an application that runs on Windows OS with the Microsoft Access database developed by BPKP as a means of assisting village governments in implementing Law Number 6 of 2016. So it can be said that the administrative process in North Hamak village has been going well.

Reporting and accountability is the final chapter in the village financial management cycle. Hamak Utara Village already has a report on the 
Fathul Mushalli et al., Sch Int J Law Crime Justice, Feb, 2021; 4(2): 117-120

realization of phase 1 and stage 2 . This report is mandatory because it is used as the main requirement for budget disbursement at the next stage. Some of the obstacles that Hamak village faced in reporting were, for example, the physical volume that was different from the report submitted. Also, the form of realization reports which sometimes varied became a separate obstacle for village officials. Based on the results of the interview, the reporting on the use of village funds consists of periodic reports and final reports. The village government is obliged to be openly accountable for reports to the BPD and the community. This is useful so that the community can find out the funds used, as well as the results obtained from the use of the village fund budget. Based on the results of the analysis of the use of village funds in terms of reports and accountability, it can be concluded that Hamak Utara Village has implemented the accountability report well.

\section{Implementasi Kebijakan Pengelolaan Dana Desa Menurut Model Edward III \\ The implementation of village fund} management in North Hamak Village has been running properly but has not been maximal in the utilization of village funds. The success of policy implementation is influenced by four variables, namely communication, resources, disposition, and bureaucratic structure. The four variables are also related to one another. Based on the results of the study, it shows that the communication relationship with the implementation of village fund project activities, there are several driving factors, namely the socialization carried out by the District / District Team, the information attainment from policymakers to policy implementers runs smoothly, and there is consistency in achieving policy messages or orders. Apart from the driving factor, of course, there are inhibiting factors, namely the absence of socialization to the community regarding the village fund policy so that the community's understanding of village funds is lacking. This will result in the emergence of suspicion from the public regarding development activities. This resulted in activity managers being afraid to use village funds so that development activities were not carried out.

Furthermore, the results showed that in the relationship between resources and the implementation of village fund management, there were several driving factors, namely the adequate completeness of village facilities and infrastructure in supporting village fund policies. While the obstacle is the low education of the activity management team so that the understanding of the implementation of the village fund project is inadequate. Likewise, the attitude aspect of the implementers has several driving factors, namely the perception of implementers who support the village fund policy and the existence of concrete actions and steps from the implementers of village funds. Meanwhile, the inhibiting factor in the implementation attitude is the doubtful attitude of the implementers of village funds in executing an activity. Furthermore, the results show that in the relationship between the organizational structure and the implementation of Village Funds, there is a driving factor in the form of an organizational structure in the form of a team for implementing village fund activities. Meanwhile, the inhibiting factors in these resources are the absence of a division of tasks among the village fund implementation team and the lack of coordination of the village fund implementation team.

\section{CONCLUSION}

Based on the research results, it can be concluded that the process of implementing village funds in Hamak village is still not going well. Even so, the process of administering the village fund budget in North Hamak Village in terms of reporting has been going well, which is carried out regularly. Besides, Hamak village has also carried out accountability well as well as the active role of the Village Consultative Body (BPD) of Hamak village in monitoring the implementation of the use of village funds. The problems that arise in the implementation of village fund management in North Hamak are the lack of socialization to the community regarding village fund policies so that the community's understanding of village funds is lacking. This will result in the emergence of public suspicion about development activities. Also, the low level of education of the activity management team has resulted in a lack of understanding of the village fund project. Also, the hesitant and very careful attitude of activity implementers in executing a project activity has become a separate obstacle in the implementation of village funds and there is no division of tasks among the implementing team for village fund activities and the lack of coordination of the village fund implementation team is also an obstacle to the management of village funds in North Hamak Village, Telaga Langsat District.

\section{REFERENCE}

1. Roza, D., \& Arliman, L. (2017). Peran Badan Permusyawaratan Desa di Dalam Pembangunan Desa dan Pengawasan Keuangan Desa. Padjadjaran Journal of Law, 4(3), pp.606-624.

2. Wasistiono, S., \& Tahir, I. (2006). Prospek Pengembangan Desa. Bandung: CV. Fokusmedia.

3. Kumalasari, D., \& Riharjo, I.B., (2016). Transparansi dan akuntabilitas pemerintah desa dalam pengelolaan alokasi Dana desa. Jurnal Ilmu dan Riset Akuntansi (JIRA), 5(11).

4. Rahman, M. (2011). Ilmu Administrasi (Vol. 1). Sah Media.

5. Undang-Undang Nomor 6 Tahun. (2014). Tentang Desa; LNRI Tahun 2014 Nomor 7; TLNRI Nomor 5495. 